Przemystaw Dąbrowski

Wydział Prawa i Administracji

Uniwersytet Warmińsko-Mazurski w Olsztynie

\title{
Towarzystwo Miłośników Historii Reformacji Polskiej im. Jana Łaskiego w Wilnie (1916-1939) - geneza, struktura prawna i działalność
}

Towarzystwo Miłośników Historii Reformacji Polskiej im. Jana Łaskiego w Wilnie, powołane w 1916 r., odegrało ważną rolę w propagowaniu dziejów reformacji na ziemiach polskich. Zawdzięczało to intensywnej działalności jego członków, organizujących liczne spotkania i wykłady. Oprócz tego Towarzystwo wydawało książki na temat Kościoła ewangelicko-reformowanego oraz wpływu, jaki reformacja wywarła na rodzącą się kulturę i język. O rosnącym prestiżu Towarzystwa może świadczyć fakt, że pod koniec działalności podwoiło liczbę członków w porównaniu z $1918 \mathrm{r}$.

The Jan Laski Society of Lovers of the History of Polish Reformation in Vilnius, established in 1916, played a significant role in the propagation of history of the Reformation in the Polish lands. This was achieved thanks to an intensive activity of its members, including numerous meetings and lectures. In addition, the Society published books on the Evangelical-Reformed Church and the impact of the Reformation on the emerging culture and language. The growing prestige of the Society can be testified by the fact that at the end of its existence it almost doubled its membership in comparison to 1918 .

Słowa kluczow e: reformacja, Towarzystwo Miłośników Historii Reformacji Polskiej im. Jana Łaskiego w Wilnie, Wilno, Kościół Ewangelicko-Reformowany 
Ke yw o rds: Reformation, The Jan Laski Society of Lovers of the History of Polish Reformation in Vilnius, Vilnius, Evangelical-Reformed Church

Podczas okupacji Wilna przez wojska niemieckie, 20 lipca 1916 r., dzięki staraniom księdza dr. Konstantego Kurnatowskiego, reprezentanta kleru ewangelicko-reformowanego ${ }^{1}$, oraz Szymona Czarnockiego ${ }^{2}$ powstała pierwsza $\mathrm{w}$ dziejach instytucja, której zadaniem była badanie historii reformacji na ziemiach polskich - Towarzystwo Miłośników Historii Reformacji Polskiej im. Jana Łaskiego w Wilnie (z siedzibą przy ul. Zawalnej 1, w budynku należącym do Synodu Wileńskiego Kościoła Ewangelicko-Reformowanego) ${ }^{3}$. Ksiądz Kurnatowski, podając zasadniczą przyczynę założenia stowarzyszenia, mówił: „Dosyć tej martwoty [- $[$, musimy sami dla siebie i dla innych drgnąć życiem" ${ }^{\prime}$. W innym miejscu zaś dodawano: „Była to jedyna tylko w Wilnie placówka, która nas Polaków różnych wyznań spajała poza wszelkimi rozdźwiękami dziś niestety istniejącymi”"

Początkowo władze niemieckie nie widziały żadnych przeszkód formalnoprawnych w działalności Towarzystwa. Dopiero w późniejszym czasie, zapewne $\mathrm{z}$ uwagi na coraz większe zainteresowanie stowarzyszeniem ze strony wiernych skupionych wokół Kościoła Ewangelicko-Reformowanego (Jednoty Wileńskiej) ${ }^{6}$, a także osób innych

${ }^{1}$ W. Gizbert-Studnicki, Stosunek Wilna do Legionów. Kartki bez retuszu z pamiętnika 1916-1917, Wilno 1928, s. 10; Jubileusz ks. prof. Konstantego Kurnatowskiego, „Szlakiem Reformacji”, 2-3, 1938, s. 33.

2 Ś. P. Szymon Czarnocki, „Szlakiem Reformacji”, 1, 1937, 1, s. 9.

${ }^{3}$ M. Brensztejn, Towarzystwo im. Jana Easkiego w Wilnie, „Reformacja w Polsce”, 2, 1921, s. 159; W. Urban, Towarzystwo Badań Dziejów Reformacji w Polsce, w: Stownik polskich towarzystw naukowych, t. 2, cz. 1: Towarzystwa naukowe i upowszechniajace naukę dziatające w przesztości na ziemiach polskich, red. B. Sordylowa, Wrocław-Warszawa-Kraków 1990, s. 204; Lietuvos Centrinis Valstybès Archyvas (dalej: LCVA), Zespół Wileńskiego Starostwa Grodzkiego, Towarzystwo Miłośników Historii Reformacji Polskiej im. Jana Łaskiego, fond 53, ap. 23, apr. 1679, Do Starostwa Grodzkiego. Referat stowarzyszeń w Wilnie, mps, Wilno, 10 III 1934 r., k. 22.

${ }^{4}$ Cyt. za: S. C[zarnocki], Nasze czwartki, „Szlakiem Reformacji”, 1-2, 1936, s. 21.

5 Cyt. za: ibidem, s. 22.

${ }^{6}$ E. Alabrudzińska, Protestantyzm w Polsce w latach 1918-1939, Toruń 2009, s. 87, 207; zob. też J. Kłaczkow, Vilnius Evangelics in the $20^{\text {th }}$ Century, w: Baltijos regiono istorija ir kultura. Lietuva ir Lenkija. Socialine istorija, kultūrologija, „Acta Historica Universitatis Klaipedensis”, 4, 2007, s. 134-139. 
wyznań ${ }^{7}$, rozpoczęto stopniowe ograniczanie jego wpływów, aż do cofnięcia wcześniej udzielonego pozwolenia ${ }^{8}$. Naturalnym faktem było więc rozpoczęcie tajnej działalności Towarzystwa, trwającej prawdopodobnie do końca roku $1918^{9}$.

Pierwsze zebranie Towarzystwa miało miejsce miesiąc po utworzeniu (22 VIII 1916). Brało w nim udział 26 osób. Wówczas ukonstytuował się również Zarząd, w składzie: prezes - ksiądz Konstanty Kurnatowski ${ }^{10}$, sekretarz - Stanisław Bohusz-Siestrzeńcewicz i skarbnik - Helena Szeferówna. Na początku 1918 r. Towarzystwo liczyło 30 członków, a jego funkcjonowanie umożliwiały uiszczane składki ${ }^{11}$. Dzięki relacji Michała Brensztejna wiadomo, że nowo powstała instytucja w głównej mierze miała się koncentrować na organizowaniu prelekcji i spotkań poświęconych sztuce, literaturze oraz historii reforma$\mathrm{cji}^{12}$. Ich adresatami byli przede wszystkim członkowie oraz zaproszeni goście $^{13}$. W okresie od 1916 do 1918 r. odbyło się kilka odczytów, wygłaszanych w ramach tzw. czwartków ewangelickich ${ }^{14}$. Skład prelegentów był jeszcze wówczas stały, a na spotkania przychodziło średnio około 30 osób:

\begin{tabular}{|l|l|l|c|}
\hline \multicolumn{1}{|c|}{ Data } & \multicolumn{1}{c|}{ Autor } & \multicolumn{1}{c|}{ Tytul } & Liczba uczestników \\
\hline 22 VIII 1916 & $\begin{array}{l}\text { ks. Konstanty } \\
\text { Kurnatowski }\end{array}$ & O Janie Easkim & 25 \\
\hline 31 X 1916 & $\begin{array}{l}\text { Stanisław Bohusz- } \\
\text { Siestrzeńcewicz }\end{array}$ & $\begin{array}{l}\text { Humanizm i jego wptyw na } \\
\text { rozwój sztuki }\end{array}$ & 30 \\
\hline 21 XII 1916 & Szymon Czarnocki & Reformacja i twórczość & 28 \\
\hline 21 XII 1916 & $\begin{array}{l}\text { ks. Konstanty } \\
\text { Kurnatowski }\end{array}$ & Proroctwa polskie w XVI wieku & 30 \\
\hline 1 II 1917 & $\begin{array}{l}\text { Kazimiera } \\
\text { Ostachiewiczowa }\end{array}$ & $\begin{array}{l}\text { Humanizm i Odrodzenie } \\
\text { oraz stosunek ich do literatury } \\
\text { polskiej }\end{array}$ & \\
\hline
\end{tabular}

${ }^{7}$ E. Alabrudzińska, Kościoty ewangelickie na kresach wschodnich II Rzeczypospolitej, Toruń 1999, s. 201; M. Kosman, Litewska jednota ewangelicko-reformowana od potowy XVII w. do 1939 r., Opole 1986, s. 93.

8 S. C[zarnocki], op. cit., s. 22.

${ }^{9}$ M. Brensztejn, op. cit., s. 160.

${ }^{10}$ M. Kosman, Litewska jednota ewangelicko-reformowana, s. 139. Po nim funkcję tę piastował Michał Jastrzębski.

${ }^{11}$ M. Brensztejn, op. cit., s. 159.

12 S. P. Szymon Czarnocki, s. 9.

${ }^{13}$ M. Brensztejn, op. cit., s. 159.

14 S. C[zarnocki], op. cit., s. 21. 


\begin{tabular}{|l|l|l|c|}
\hline \multicolumn{1}{|c|}{ Data } & \multicolumn{1}{c|}{ Autor } & \multicolumn{1}{c|}{ Tytuł } & Liczba uczestników \\
\hline 8 XI 1917 & $\begin{array}{l}\text { ks. Konstanty } \\
\text { Kurnatowski }\end{array}$ & Koniec arjan polskich & 28 \\
\hline 8 XI 1917 & Szymon Czarnocki & Cztowiek przysztości & 28 \\
\hline 3 I 1918 & $\begin{array}{l}\text { Stanisław Bohusz- } \\
\text { Siestrzeńcewicz }\end{array}$ & O Józefie Chetmońskim & 51 \\
\hline 23 I 1918 & $\begin{array}{l}\text { ks. Konstanty } \\
\text { Kurnatowski }\end{array}$ & $\begin{array}{l}\text { Swiatopoglad Juliusza } \\
\text { Stowackiego }\end{array}$ & 27 \\
\hline
\end{tabular}

Źródło: oprac. własne na podstawie: M. Brensztejn, Towarzystwo im. Jana Łaskiego $w$ Wilnie, „Reformacja w Polsce”, 2, 1921, s. 159-160.

Towarzystwo działało dość prężnie do połowy roku 1918. Później, jak odnotował Brensztejn, nie podejmowało większych inicjatyw ${ }^{15}$. Stan taki trwał prawdopodobnie do 1922 r., kiedy to uregulowano status Ziemi Wileńskiej. W nowej rzeczywistości prawno-ustrojowej Towarzystwo rozpoczęło ożywioną działalność, a oznaką nadchodzących zmian było sporządzenie i zatwierdzenie (6 VI 1923) nowego statutu Towarzystwa. Jego autorami byli: Bronisław Iżycki Herman, ksiądz Michał Jastrzębski ${ }^{16}$, Aleksander Proniewicz i adwokaci: Bolesław Szyszkowski oraz Eugeniusz Falkowski ${ }^{17}$. Jako główne cele (o charakterze apolitycznym) przyjęto m.in. badanie historii reformacji na ziemiach polskich, ich upublicznianie w formie drukowanej, zbieranie oraz „przechowywanie pomników reformacji”, zwoływanie konferencji oraz wygłaszanie prelekcji, organizowanie konkursów wiedzy, przyznawanie nagród i stypendiów „dla uczącej się młodzieży”, „udzielanie zapomóg pozostałym po członkach wdowom i sierotom”, tworzenie i udzielanie pomocy wyższym zakładom naukowym ${ }^{18}$. Ponadto ogromny nacisk kładziono na pamięć o minionych wydarzeniach, podkreślano wagę tolerancji religijnej i zasad wypływających $\mathrm{z}$ fundamentów sprawiedliwości ${ }^{19}$. Przypominano również o znaczeniu reformacji na ziemiach polskich oraz jej wpływie na dziedzictwo kulturowe. Pisano:

${ }^{15}$ M. Brensztejn, op. cit., s. 160.

16 J. Szturc, Stowarzyszenia spoteczno-kulturalne w polskim ewangelicyzmie, Warszawa 2006, s. 29.

${ }^{17}$ LCVA, Towarzystwo Miłośników Historii Reformacji Polskiej im. Jana Łaskiego, fond 290, ap. 1, apr. 1, Statut Towarzystwa Miłośników Historii Reformacji Polskiej im. Jana Łaskiego, Wilno, 1927, s. 8.

18 Ibidem, s. 2.

${ }_{19}$ W obronie prawdy $i$ w sprawie akcji wyborczej, Wilno 1928, s. 2. 
Reformacja przyczyniła się do powstania Akademii jezuickiej w Wilnie, założonej w celu zwalczania protestantyzmu i tylko tak długo kwitnącej, jak długo Reformacja nie przestawała być siłą i bodźcem do utrzymania Akademii na odpowiednio wysokim poziomie, mogącym konkurować z ruchem umysłowym wytworzonym przez Reformację. $Z$ powstaniem Reformacji w Polsce nie tylko w większych miastach, ale i we wsiach, dziś w najgłuchszych kątach leżących, powstały liczne oficyny drukarskie, skąd wychodziło wolne słowo, najczęściej po raz pierwszy w języku polskim i wprowadziło język polski do literatury polskiej, posługującej się panującą uprzednio łaciną. [- - ] Nie unia religijna, ale Reformacja i wywołany przez nią ruch umysłowy był tym czynnikiem, który rozszerzał we wschodnich połaciach Rz[eczy]po[spo]litej język polski i pogłębił kulturę polską ${ }^{20}$.

Przytoczone wyżej wyznaczone zadania miały być osiągnięte przede wszystkim poprzez: zwoływanie zebrań, organizację odczytów, balów i zabaw o charakterze towarzyskim, wydawanie gazet, książek o tematyce związanej z historią reformacji, utrzymywanie biblioteki i czytelni, stworzenie funduszu do finansowania zapomóg i stypendiów, nabywanie nieruchomości ${ }^{21}$. $\mathrm{Na}$ dochody Towarzystwa, służące realizacji powyższych celów statutowych, składały się m.in. składki uiszczane przez członków, darowizny, dochody „zwyczajne" i te uzyskiwane z publikacji oraz organizowanych imprez okolicznościowych, „odsetki od kapitału” ${ }^{22}$ oraz nabyte „ruchomości i nieruchomości”23.

Towarzystwo - ze stałą siedzibą w Wilnie - mogło działać na terenie Ziemi Wileńskiej, a od 1926 r. - województwa wileńskiego. Miało także prawo do tworzenia oddziałów. Członkiem rzeczywistym mógł zostać obywatel państwa polskiego, który złożył pisemną aplikację oraz na mocy uchwały Zarządu włączono go do struktur stowarzyszenia; członkiem honorowym natomiast - „każdy obywatel Kraju polskiej narodowości” pod warunkiem, że Ogólne Zebranie przyjęło go „większością $2 / 3$ głosów” 24 . Z szeregów Towarzystwa dana osoba mogła wystąpić samodzielnie (wniosek był wówczas kierowany do

${ }^{20}$ Ibidem, s. 1.

${ }^{21}$ LCVA, Towarzystwo Miłośników Historii Reformacji Polskiej im. Jana Łaskiego, fond 290, ap. 1, apr. 1, Statut Towarzystwa Miłośników Historii Reformacji Polskiej im. Jana Łaskiego, Wilno, 1927, s. 2-3.

22 Ibidem, s. 8; jak zaznaczono: „Kapitał [- - lokuje się w papierach procentowych, w instytucjach finansowych lub na pierwszych numerach hipoteki”.

${ }^{23}$ Ibidem, s. 8.

${ }^{24}$ Ibidem, s. 3. Członkostwo honorowe można było łączyć z rzeczywistym. 
Zarządu) oraz w przypadku nieuiszczania składki (przez okres co najmniej trzech lat ${ }^{25}$.

Władze Towarzystwa stanowiły: Ogólne Zebranie i Zarząd. To do tych właśnie organów należało kierowanie instytucją. Ogólne Zebranie wybierało też Zarząd oraz Komisję Rewizyjną, przyjmowało roczne sprawozdania Zarządu, akceptowało protokoły obrad Ogólnych Zebrań, rozstrzygało wnioski składane przez Zarząd, Komisję Rewizyjną oraz poszczególnych członków, decydowało o zmianie statutu, zatwierdzeniu regulaminów, kwestiach majątkowych (w tym budżetowych, spadkach, darowiznach), delegalizacji Towarzystwa i pozbawieniu członkostwa ${ }^{26}$. Ogólne Zebrania były zwoływane co roku przez Zarząd i przybierały wówczas charakter sprawozdawczych. Mogły przybrać również formę comiesięcznych spotkań (w pierwszą niedzielę każdego miesiąca), a także nadzwyczajnych - zwoływanych w sytuacjach „nagłych”. Wtedy z wnioskiem występował Zarząd, Komisja Rewizyjna lub „co najmniej 10 członków rzeczywistych”. Ogłoszenie o spotkaniu umieszczano „w jednym z pism wileńskich” oraz informowano każdego członka osobno z tygodniowym wyprzedzeniem. Kworum niezbędne do prawomocności podejmowanych przez Ogólne Zebranie uchwał (zebrania roczne i nadzwyczajne) stanowiło „co najmniej 1/10 wszystkich członków rzeczywistych”, jednakże bez uwzględnienia członków Zarządu ${ }^{27}$. Natomiast w sprawach związanych ze zmianą statutu i z likwidacją Towarzystwa wymagana była obecność jednej trzeciej „ogólnej liczby rzeczywistych członków" 28 . Uchwały co do zasady zapadały zwykłą większością głosów ${ }^{29}$.

Zarząd Towarzystwa złożony był z pięciu członków i trzech zastępców. Jego skład (tj. prezesa, wiceprezesa, sekretarza i skarbnika) wyłaniało na okres trzech lat Ogólne Zebranie. Zarząd reprezentował Towarzystwo na zewnątrz oraz „prowadził” jego sprawy. Odpowiadał za zwoływanie Ogólnych Zebrań oraz wykonanie wszystkich przyjętych uchwał, a dodatkowo przygotowywał budżet i jego preliminarz, „prowadził prawidłową" księgowość oraz rachunkowośćc ${ }^{30}$.

${ }^{25}$ Ibidem, s. 3, 4. Wysokość składki miała charakter symboliczny i wynosiła 1 zł na rok. Mogła ulec zmianie jedynie poprzez postanowienie Ogólnego Zebrania. W 1925 r. oznaczono ją na 50 gr miesięcznie.

${ }^{26}$ Ibidem, s. 4, 5 .

27 Ibidem, s. 5.

${ }^{28}$ Ibidem, s. 5, 6.

29 Ibidem, s. 6 .

${ }^{30}$ Ibidem, s. 6, 7. 
„Dla sprawdzenia i kontroli rachunkowości” z kolei powoływano Komisję Rewizyjną, której członkowie byli desygnowani na rok przez Ogólne Zebranie. Składała się ona z członków rzeczywistych (3) oraz zastępcy. Osoby te nie mogły zasiadać w Zarządzie. Posiedzenia Komisji (w celu przejrzenia dokumentów) były zwoływane przynajmniej raz $\mathrm{w}$ roku ${ }^{31}$.

W dwudziestoleciu międzywojennym Towarzystwo wydawało własnym sumptem różne prace poświęcone historii reformacji na ziemiach byłej Rzeczypospolitej Obojga Narodów, w tym m.in. serię Monumenta Reformationis Polonicae et Lithuanicae ${ }^{32}$. W pierwszej połowie 1938 r. zapowiedziano też opublikowanie - nakładem Synodu Wileńskiego Kościoła Ewangelicko-Reformowanego - akt zboru kiejdańskiego z lat $1628-1665^{33}$. Aby to uczynić, powołano do życia Komitet Redakcyjny w składzie: Wacław Gizbert Studnicki, Walerian Kwiatkowski i Włodzimierz Sakowicz ${ }^{34}$. Angażowano się również w wydarzenia o charakterze kulturalnym i społecznym, co dwa tygodnie organizowano „wieczory dyskusyjne” o tematyce religijno-historycznej ${ }^{35}$, zebrania (także te o charakterze naukowym) oraz akademie $^{36}$. Ponadto wspomagano finansowo wileńskie przedszkola ${ }^{37}$.

31 Ibidem, s. 7.

32 M. Kosman, Badania nad reformacja w Wielkim Księstwie Litewskim, OiRwP, 16, 1971, s. 145; E. Alabrudzińska, Protestantyzm w Polsce, s. 207; H. Merczyng, Wilno ewangelickie, Wilno 1925, s. 1-16; W. Gizbert Studnicki, Rys historyczny Archiwum i Biblioteki Synodu Ewangelicko-Reformowanego w Wilnie, Wilno 1929, s. 1-16; Zarys historyczny wileńskiego kościota ewangelicko-reformowanego i jego biblioteki (z dodatkiem), oprac. W. Gizbert Studnicki, Wilno 1932, s. 1-31; Album zabytków ewangelickich $w$ Wilnie, Wilno 1929, s. 1-73.

33 J. Szturc, op. cit., s. 29. Podjęta inicjatywa zakończyła się niepowodzeniem, z uwagi na wybuch II wojny światowej.

${ }^{34}$ LCVA, Zespół Wileńskiego Starostwa Grodzkiego, Towarzystwo Miłośników Historii Reformacji Polskiej im. Jana Łaskiego, fond 53, ap. 23, apr. 1679, Sprawozdanie z działalności T[owarzyst]wa im. Jana Łaskiego za r. 1937/38, rkps, k. 3.

35 P. Dilis, Rzut oka na pracę kościelno-spoteczna Wileńskiego Kościota Ewangelicko-Reformowanego w roku synodalnym 1936-37, „Szlakiem Reformacji”, 3-4, 1937, s. 20; Synod Wilenski Ewangelicko-Reformowany, „Szlakiem Reformacji”, 5, 1939, s. 2.

36 Synod Wileński Ewangelicko-Reformowany, s. 2; K. Kurnatowski, Kościót Ewangelicki w Litwie, „Szlakiem Reformacji”, 5, 1939, s. 8-12; LCVA, Zespół Wileńskiego Starostwa Grodzkiego, Towarzystwo Miłośników Historii Reformacji Polskiej im. Jana Łaskiego, fond 53, ap. 23, apr. 1679, Sprawozdanie z działalności T[owarzyst]wa im. Jana Łaskiego za r. 1937/38, rkps, k. 3; ibidem, Do Starostwa Grodzkiego w Wilnie, mps, Wilno, 24 IV 1936 r., k. 16; ibidem, Do Pana starosty grodzkiego wileńskiego, mps, Wilno, 26 X 1932 r., k. 26; ibidem, 
Od stycznia 1936 do sierpnia 1939 r. organem prasowym Towarzystwa był miesięcznik zatytułowany "Szlakiem Reformacji”38. Siedziba redakcji mieściła się w Wilnie przy ul. Zawalnej $11 / 4^{39}$. Redaktorem (do czerwca 1938 r.) był ksiądz Michał Jastrzębski superintendent generalny Wileńskiego Kościoła Ewangelicko-Reformowanego ${ }^{40}$, redaktorem odpowiedzialnym - ksiądz Aleksander Piasecki, wydawcą zaś początkowo Bronisław Iżycki Herman - prezydent Konsystorza Wileńskiego Kościoła Ewangelicko-Reformowanego $^{41}$, a następnie Synod Wileńskiego Kościoła Ewangelicko-Reformowanego. W słowie wstępnym, skierowanym do czytelników pisma, zauważono, że miało ono służyć „wskrzeszeniu wiary ewangelicznej” oraz być „symbolem i znakiem naszego życia w Wolnej i Odrodzonej Ojczyźnie naszej”².

U schyłku działalności Towarzystwa funkcję jego prezesa pełnił, ponownie wybrany na to stanowisko 27 marca 1938 r., Wacław Gizbert Studnicki ${ }^{43}$, wiceprezesa - ksiądz pastor Zygfryd Loppe ${ }^{44}$,

Do Pana starosty grodzkiego wileńskiego, mps, Wilno, 31 X 1931 r., k. 32; ibidem, Do Pana starosty grodzkiego, rkps, Wilno, 17 I 1931 r., k. 39; ibidem, Towarzystwo Miłośników Historii Reformacji Polskiej, k. 29; ibidem, Towarzystwo Miłośników Historii Reformacji Polskiej zapoczątkowało cykl odczytów, k. 37; ibidem, Do Starostwa Grodzkiego. Referat stowarzyszeń w Wilnie, k. 22. W latach 1931-1939 wygłoszono m.in. następujące prelekcje: W. Sakowicz, Konferencja Warszawska w r. 1573; idem, Rola M. Grużewskiej w dziejach Kościota Ewangelicko-Reformowanego na Żmudzi; W. Gizbert Studnicki, Stefan Oskierko, emigrant religijny w wieku XVIII; idem, Usitowanie rusyfikacji Kościota rzymskokatolickiego na terenie Ziem Wschodnich Rzeczypospolitej Polskiej; idem, Przyczyny walki kleru z rządem Litwy Kowieńskiej; K. Kurnatowski, Kościoty protestanckie w Litwie; S. Kot, O biblii Chylińskiego; B. Szyszkowski, Sztuka i religia; P. Krzewski, O reformacji w kulturze staropolskiej; S. Czarnocki, Wrażenia z pobytu $w$ Matopolsce Wschodniej wśród Rusinów, ewangelików reformowanych; a także zorganizowano m.in. akademie poświęcone Tadeuszowi Hołówce oraz „ku czci 400-lecia Ulricha Zwingli'ego reformatora szwajcarskiego".

37 LCVA, Towarzystwo Miłośników Historii Reformacji Polskiej im. Jana Łaskiego, fond 290, ap. 1, apr. 2, Księga kasowa 1931-1937, b.pag.

38 W latach 1937-1938 pismo wychodziło jako dwumiesięcznik.

${ }^{39}$ Od 1937 r. przy ul. Zawalnej 11/5.

40 Życiorys ś. p. Ks. Sen. M. Jastrzębskiego Superintendenta Gener. Jednoty Wileńskiej, "Szlakiem Reformacji”, 4, 1938, s. 2.

41 25-letni jubileusz p. B. Iżyckiego Hermana, „Szlakiem Reformacji”, 3-4, 1936, s. 25.

${ }^{42}$ M. Jastrzębski, Stowo do Czytelników!, „Szlakiem Reformacji”, 1-2, 1936, s. 1, 2.

43 Wacław Gizbert Studnicki był prezesem Towarzystwa prawdopodobnie od $1930 \mathrm{r}$.

${ }^{44}$ E. Alabrudzińska, Kościoty ewangelickie na kresach, s. 201. 
sekretarza - Włodzimierz Sakowicz, skarbnika - Aleksander Meyer, a członka Zarządu - Walerian Kwiatkowski ${ }^{45} .2$ października 1938 r. natomiast księdzu Kurnatowskiemu przyznano zaszczytny tytuł prezesa honorowego ${ }^{46}$. Pod koniec lat trzydziestych Towarzystwo niemalże podwoiło liczbę członków, liczyło bowiem 53 osoby $^{47}$.

Powstałe w 1916 r. Towarzystwo odegrało znaczącą rolę w badaniu historii reformacji na ziemiach polskich. Udało się to dzięki intensywnej działalności jego członków, często organizowanym spotkaniom i wykładom, a także publikacji prac poświęconych znaczeniu Kościoła ewangelicko-reformowanego i wpływowi reformacji na kształtująca się kulturę i język.

\section{Bibliografia}

\section{Źródła}

Lietuvos Centrinis Valstybės Archyvas (LCVA), Towarzystwo Miłośników Historii Reformacji Polskiej im. Jana Łaskiego, fond 290, ap. 1, apr. 1 Lietuvos Centrinis Valstybės Archyvas (LCVA), Zespół Wileńskiego Starostwa Grodzkiego, Towarzystwo Miłośników Historii Reformacji Polskiej im. Jana Łaskiego, fond 53, ap. 23, apr. 1679

25-letni jubileusz p. B. Iżyckiego Hermana, „Szlakiem Reformacji”, 3-4, 1936

${ }^{45}$ LCVA, Zespół Wileńskiego Starostwa Grodzkiego, Towarzystwo Miłośników Historii Reformacji Polskiej im. Jana Łaskiego, fond 53, ap. 23, apr. 1679, Arkusz ewidencyjny, k. 1; ibidem, Do Urzędu Wojewódzkiego Wileńskiego, mps, Wilno, 21 III 1934 r., k. 21; ibidem, Do Urzędu Wojewódzkiego Wileńskiego. Wydział Bezpieczeństwa, mps, Wilno, 23 XI 1932 r., k. 24; ibidem, Do Pana starosty grodzkiego wileńskiego, mps, Wilno, 26 X 1932 r., k. 25; ibidem, Do Starostwa Grodzkiego w Wilnie, mps, Wilno, 24 IV 1936 r., k. 16; Synod Wileński Ewangelicko-Reformowany, s. 2. W latach 1932-1934 w skład Zarządu wchodzili: Wacław Gizbert Studnicki (prezes), Zygfryd Loppe (zastępca), Aleksander Meyer (skarbnik), Gustaw Przewłocki (sekretarz). Członkami Zarządu byli: ks. Michał Jastrzębski, ks. Paweł Dilis i Czesław Reychman. W latach 1935-1937 w skład Zarządu wchodzili: Wacław Gizbert Studnicki (prezes), Zygfryd Loppe (zastępca), Aleksander Meyer (skarbnik), Jadwiga Loppe (sekretarz). Obowiązki członków Zarządu pełnili: ks. Michał Jastrzębski, ks. Paweł Dilis i Czesław Reychman.

46 Synod Wileński Ewangelicko-Reformowany, s. 2.

${ }^{47}$ LCVA, Zespół Wileńskiego Starostwa Grodzkiego, Towarzystwo Miłośników Historii Reformacji Polskiej im. Jana Łaskiego, fond 53, ap. 23, apr. 1679, Sprawozdanie z działalności T[owarzyst]wa im. Jana Łaskiego za r. 1937/38, rkps, k. 3. 
M. Brensztejn, Towarzystwo im. Jana Easkiego w Wilnie, „Reformacja w Polsce", 2, 1921

S. C[zarnocki], Nasze czwartki, „Szlakiem Reformacji”, 1-2, 1936

P. Dilis, Rzut oka na pracę kościelno-spoteczna Wileńskiego Kościota Ewangelicko-Reformowanego w roku synodalnym 1936-37, „Szlakiem Reformacji”, 3-4

W. Gizbert-Studnicki, Stosunek Wilna do Legionów. Kartki bez retuszu z pamiętnika 1916-1917, Wilno 1928

M. Jastrzębski, Stowo do Czytelników!, „Szlakiem Reformacji”, 1-2, 1936

Jubileusz ks. prof. Konstantego Kurnatowskiego, „Szlakiem Reformacji”, 2-3, 1938

K. Kurnatowski, Kościót Ewangelicki w Litwie, „Szlakiem Reformacji”, 5, 1939

Synod Wileński Ewangelicko-Reformowany, „Szlakiem Reformacji”, 5, 1939

S. P. Szymon Czarnocki, „Szlakiem Reformacji”, 1, 1937

W obronie prawdy i w sprawie akcji wyborczej, Wilno 1928

Życiorys s. p. Ks. Sen. M. Jastrzębskiego Superintendenta Gener. Jednoty Wileńskiej, „Szlakiem Reformacji”, 4, 1938

\section{Opracowania}

E. Alabrudzińska, Kościoty ewangelickie na kresach wschodnich II Rzeczypospolitej, Toruń 1999

E. Alabrudzińska, Protestantyzm w Polsce w latach 1918-1939, Torun 2009 Album zabytków ewangelickich $w$ Wilnie, Wilno 1929

W. Gizbert Studnicki, Rys historyczny Archiwum i Biblioteki Synodu Ewangelicko-Reformowanego $w$ Wilnie, Wilno 1929

J. Kłaczkow, Vilnius Evangelics in the $20^{\text {th }}$ Century, w: Baltijos regiono istorija ir kultura. Lietuva ir Lenkija. Socialine istorija, kultūrologija, „Acta Historica Universitatis Klaipedensis”, 4, 2007

M. Kosman, Badania nad reformacja w Wielkim Księstwie Litewskim, OiRwP, 16, 1971

M. Kosman, Litewska jednota ewangelicko-reformowana od potowy XVII w. do 1939 r., Opole 1986

H. Merczyng, Wilno ewangelickie, Wilno 1925

W. Urban, Towarzystwo Badań Dziejów Reformacji w Polsce, w: Stownik polskich towarzystw naukowych, t. 2, cz. 1: Towarzystwa naukowe i upowszechniajace naukę dziatające w przesztości na ziemiach polskich, red. B. Sordylowa, Wrocław-Warszawa-Kraków 1990

Zarys historyczny wileńskiego kościoła ewangelicko-reformowanego i jego biblioteki (z dodatkiem), oprac. W. Gizbert Studnicki, Wilno 1932 


\section{The Jan Laski Society of Lovers of the History of Polish Reformation in Vilnius (1918-1939) - Genesis, Legal Structure and Activity}

The Jan Laski Society of Lovers of the History of Polish Reformation in Vilnius, established in 1916, played a significant role in the propagation of history of the Reformation in the Polish lands. This was achieved thanks to an intensive activity of its members, including numerous meetings and lectures. In addition, the Society published books on the Evangelical-Reformed Church and the impact of the Reformation on the emerging culture and language.

An important part in setting up the association was played by Konstanty Kurnatowski. Initially, the Society was open, but after the German authorities decided to suspend its activities, a secret period began, which lasted until the end of 1918. The Society was managed by the General Assembly and Board. From January 1936 to August 1939, the Society issued its own periodical under the title of The Trail of Reformation. The seat of the editorial office was in Vilnius. The growing prestige of the Society can be testified by the fact that at the end of its existence it almost doubled its membership in comparison to 1918.

Przemysław Dąbrowski, profesor nadzwyczajny na Wydziale Prawa i Administracji Uniwersytetu Warmińsko-Mazurskiego w Olsztynie. Na jego dotychczasowy dorobek naukowy składa się pięć książek i kilkadziesiąt artykułów, dotyczących kształtowania się polskiej myśli politycznej, a także stosunków polsko-litewskich na ziemiach litewsko-białoruskich w drugiej połowie XIX i pierwszej połowie XX w.

Przemysław Dąbrowski, associate professor at the Faculty of Law and Administration of the University of Warmia and Mazury in Olsztyn. He is the author of five books and several dozen of studies and articles on the development of Polish political thought, and also on the Polish-Lithuanian relations in the Lithuanian-Belarusian lands in the second half of the $19^{\text {th }}$ century and early part of the $20^{\text {th }}$ century.

E-mail: przemyslaw.dabrowski@uwm.edu.pl 